\title{
POTRET ISLAM NUSANTARA PADA TRADISI BASAFA DI KENAGARIAN ULAKAN PADANG PARIAMAN
}

\author{
Nafri Andy. N \\ IAIN Bukittinggi \\ Email: nafri_andi@yahoo.co.id
}

\begin{abstract}
Abstrak
Agama dan kehidupan sosial di masyarakat merupakan dua sisi mata uang yang tidak dapat dipisahkan. Ikatan sosial, kohesi sosial, dan solidaritas yang kokoh akan ditentukan dengan adanya nilai-nilai kesamaan yang hidup di masyarakat, yaitu nilai-nilai agama. Penelitian ini mencoba mengungkap hubungan antara tradisi yang ada di dalam masyarakat dengan nilai-nilai agama yang akrab dikenal dengan Islam Nusantara. Penelitian ini menggunakan pendekatan kualitatif dengan teknik pengumpulan data wawancara dan observasi. Temuan dari riset ini adalah tradisi basafa yang kerap dilakukan oleh masyarakat merupakan bagian dari akulturasi budaya yang dapat menumbuhkan sikap hormat dan takzim kepada ulama yang berasal dari Nusantara.
\end{abstract}

Keywords: Islam, Nusantara, tradisi, basafa dan nagari

\section{PENDAHULUAN}

Negara Indonesia yang terdiri dari berbagai pulau dan memiliki karakter penduduk yang berbeda-beda dapat dilihat dari beragamnya tradisi masyarakat dalam melaksanakan ibadah. Isu Islam Nusantara semakin menarik diperdebatkan setelah ide ini lama vakum dan kembali dilempar oleh Said Aqil Siraj dengan mencirikan sebagai Islam ramah, anti radikal, inklusif, dan toleran. Isu ini juga semakin menggeliat setelah Said Aqil Siraj menambahkan penjelasan dengan membedakan Islam Nusantra dengan Islam Arab yang selalu diselimuti konflik dan perang saudara. Isu ini juga semakin menjadi-jadi dan ada juga sebagian kelompok yang menggolongkan Islam Nusantara sebagai bagian asing dalam merusak Islam dari sudut pandang praktek beragama. Dalam artikel ini penulisan ditujukan untuk menganalisis konsep Islam Nusantara dengan menghubungkannya dengan tradisi lokal yang ada di Sumatera Barat, yaitu tradisi basafa yang kerap dilakukan oleh jamaah syatariyah untuk mengenang hari kelahiran Syekh Burhanuddin sebagai penyebar Islam pertama di Sumatera Barat.

\section{METODE PENELITIAN}

Jenis penelitian ini adalah penelitian kualitatif. Penelitian ini tergolong penelitian lapangan yang mengungkapkan tradisi basafa yang dilakukan di Makam Syekh Burhanuddin. Penelitian ini juga bersifat deskriptif yang menggambarkan perilaku keberagamaan yang dilakukan oleh masyarakat Padang Pariaman dalam kegiatan tahunan yaitu basafa. Sumber data yang digunakan dalam riset ini adalah primer dan sekunder. Data primer dari penelitian dapat berupa hasil wawancara dan observasi. Sedangkan data sekunder berupa catatan yang berkaitan dengan kegitan basafa dan riset-riset lain sebelumnya. 


\section{HASIL \\ PENELITIAN \\ PEMBAHASAN}

\section{Membangun Peradaban Melalui Konsep Islam Nusantara}

Menarik menyimak statemen yang diucapkan oleh Presiden Indonesia yang ke-7 Joko Widodo "Alhamdulillah Islam kita Islam Nusantara, Islam yang penuh sopan santun, penuh tata krama, dan toleransi". Dalam penuturan beliau dijelaskan bahwa karakteristik ber-Islam-nya muslim Indonesia adalah memiliki sopan santun dan ramah dalam menyampaikan dakwahnya. Populernya Islam Nusantara semenjak ide ini dilemparkan oleh Said Agil Siradj pada Istigasah Menyambut Ramadhan dan Pembukaan Munas Alim Ulama NU 14 Juni 2015, menurut beliau NU akan terus memperjuangkan dan mengawal model Islam Nusantara. Islam Nusantara yang dimaksud adalah upaya penyebaran Islam Nusantara melalui pendekatan budaya tidak dengan doktrin yang kaku dan keras (Mohamad Guntur Romli, 2016).

Islam Nusantara merupakan gabungan dari dua kata, Islam dan Nusantara. Islam merupakan agama yang dibawa oleh Nabi Muhammad dan selanjutntnya berkembang ke seluruh penjuru dunia. Sedangkan Nusantara adalah wilayah atau kawasan yang merujuk pada Indonesia dan sekitarnya di Asia Tenggara, namun tidak mencakup secara keseluruhan karena tidak semua Asia Tenggrara dimasuki oleh Islam. Terdapat dua pemahaman ketika mengkaji Islam Nusantara, pertama: kalangan, kelompok dan masyarakat Islam yang ada di wilayah Nusantara. Kedua, Islam yang memiliki corak tertentu dan berinteraksi secara luwes dengan tradisi atau khazanah Nusantara. Dari dua kemungkinan di atas, pernyataan pertama menjadi gugur karena nusantara yang dikaitkan dengan Islam bermakna ajektif, sifat dan penyifatan. Sama seperti Islam Arab, Islam Afrika, dan Islam kawasan lain. Selintas dipahami bahwa Islam yang ada di kawasan tersebut, padahal ketika Islam disambung dengan Nusantara, Arab dan Afrika kata ini memiliki karakter dan sifat yang tertentu (JNM, 2015).

Maka dapat ditarik pemahaman bahwa Islam Nusantara adalah Islam yang memiliki karakter dan bercorak Nusantara yang mengakomodir tradisi dan alam pikiran orang Nusantara serta berpijak pada nilai-nilai Islam. Dalam metode dakwah, baiknya kita merujuk seperti apa yang telah dilakukan oleh Wali Songo. Sunan Kalijaga sangat toleran pada budaya lokal. Ia berpandangan bahwa masyarakat akan menjauh bila pendirian mereka diserang. Dalam berdakwah beliau menggunakan seni ukir, wayang, gamelan serta seni suara. Beliau juga memprakarsai baju takwa, perayaan sekatenan, grebeg maulud, layang kalisada, dan lakon wayang petruk jadi raja. Lanskap puata kota memiliki kraton, alun-alun yang berdampingan dengan masjid juga merupakan karya beliau (Afifuddin Muhajir, 2015).

Menurut Azyumardi Azra istilah Islam Nusantara mengacu pada Islam yang berada pada gugusan kepulauan atau benua maritim yang mencakup Malaysia, Thailand Selatan (Patani), Singapura, Filipina Selatan (Moro), dan Champa (Kampuchea). Padanan kata yang tepat dari penjelasan tersebut adalah Islam Asia Tenggara (Southeast Asian Islam), namun istilah yang masyhur digunakan adalah Islam Melayu. Secara doktrin penamaan Islam Nusantara cenderung menganut rukun iman dan rukun Islam yang dipahami oleh kelompok Ahl al-Sunnah wa al-Jama'ah. Yang menjadi distingsi Islam Nusantara adalah ortodoksi Islam Nusantara yang mulai nampak setelah abad 17 ketika 
murid dari Jawi seperti ar-Raniry, Abdurrauf As-Singkil, dan Yusuf alMaqasari kembali ke Nusantara setelah hampir dua dasawarsa belajar di Makkah dan Madinah (Azyumardi Azra, 2015).

Karakter dari ortodoksi Islam Nusantara terdapat pada tiga hal, di antaranya: teologi mengikuti Asy'ari, fiqh menggunakan Asy-Syafii, dan tasawuf mengikuti al-Ghazali. Sedangkan ortodoksi Saudi meliputi: Pertama, teologi Salafi-Wahabi dengan pemahaman tekstual dan Islam yang murni. Kedua, fiqh Hambali yang cenderung ketat dalam yurisprudensi Islam. Mereka juga menganggap tasawuf bagian dari kesesatan.

Proses islamisasi yang terjadi di Indonesia memberikan gambaran bahwa telah terjadi kontak dan dinamika yang panjang dalam upaya pengembangan dakwah Islam, sebagaimana yang dikemukakan oleh (Uka Tjandrasamita, 2009) di antaranya: Pertama, kedatangan Islam ke beberapa pantai melayu mengikuti rute pelayaran dan perdagangan dari Arab-Persia-Indiadunia Melayu-Tiongkok. Pedagang muslim selain bekerja sebagai pedagang juga melakukan dakwah bagi orang di wilayah asing. Pedagang muslim yang pergi wilayah perdagangan biasanya tidak pulang dengan segera karena masih menunggu barangterjual dan membeli barang untuk dijual kembali di negara mereka; Kedua, perkawinan, hubungan yang baik antara pedagang Muslim dan komunitas lokal memberikan peluang untuk membentuk keluarga besar dengan cara pernikahan. Keinginan komunitas lokal untuk menikah dengan pedagang Muslim karena memiliki ekonomi yang kuat serta status yang tinggi sehingga menarik minat raja untuk menikahkan putri mereka dengan pedagang tersebut; Ketiga, di Tanah Jawa, proses islamisasi terjadi di tangan sembilan orang suci
(Wali Songo) terdiri dari: (1) Sunan Ampel/Sunan Rahmat (2) Sunan Giri (3) Sunan Bonang (4) Sunan Gunung Jati (5) Sunan Muria (6) Sunan Kali Jaga (7) Sunan Drajat (8) Sunan Kudus (9) Sunan Lemah Abang Syekh Siti Jenar. Peran wali songo ini dalam proses islamisasi dilakukan dengan cara perangai yang terpuji dan pendekatan sesuai dengan budaya lokal: Keempat, Sufisme, tradisi sufisme juga digunakan oleh para pedagang dalam mengembangkan Islam di Nusantara. Sufi dilibatkan langsung dalam proses penyebaran Islam di Indonesia dan sebagian daerah di dunia Melayu. Sifat khusus sufisme adalah memfasilitasi penyerapan komunitas non-muslim ke dalam ikatan Islam. peran sufisme menggunakan jalur tasawuf dalam proses islamisasi sangat berpengaruh besar. Sejarah sufisme juga mengungkap bahwa seorang sufi juga bergantung pada dukungan para raja dalam menyebarkan ajaran mereka. Hal ini terlihat dari ide Hamzah Fansur didukung oleh Sultan Iskandar Muda dan ditolak oleh Iskandar Tsani; Kelima, penyebaran Islam juga dilakukan melalui lembaga pendidikan seperti pesantren. Siswanya juga disebut dengan santri sementara gurunya disebut guru ngaji, kyai atau ajengan.

Dari penjelasan di atas dapat dipahami bahwa Islam yang datang ke tanah melayu berasal dari jaringan Arab, Persia, India, bahkan mungkin juga datang dari Tiongkok. Menyebarnya Islam di Nusantara dikembangkan dengan berbagai metode dan profesi seperti pedagang, mubaligh, atau pengajar agama bahkan juga berasal dari sufi. Dari sini jelas bahwa Islam Nusatara datang ke tanah Melayu melalui akulturasi dan menghargai kultur setempat sehingga tidak ada persfektif menjajah dan memaksa ketika menyebarkan Islam. 
Perpaduan Nilai Agama dan Budaya Lokal dalam Praktek Keagamaan di Indonesia

Menurut Quraisy Shihab sebagaimana di kutip oleh Muhammad Sholikhin Islam hadir bukan di ruangan hampa. Namun telah ditemukan adat istiadat dan perilaku masyarakat sebelumnya, adat yang baik tetap dipertahankan oleh Islam sedangakan adat jelek ditolak dan ditinggalkan. Contohnya adalah sistem anak angkat pada masa jahiliyah diadopsi dan diperbaharui dengan adanya pembolehan anak angkat namun tidak seperti keberadaan anak kandung. Oleh sebab itu, anak angkat tidak berhak untuk mendapatkan harta warisan walaupun boleh seorang ayah angkat tadi berwasiat tidak lebih dari 1/3 harta warisan Muhammad Sholikhin, 2010).

Kebudayaan yang berkembang di Indonesia menurut Kuntowijoyo terdapat dalam dua bentuk: budaya keraton dan budaya populer. Panggung sejarah di Indonesia membuktikan bahwa transformasi Islam pada dua level tersebut memang ada namun dengan pola dan produk budaya yang berbeda. Pengaruh Islam yang terdapat pada level istana adalah adanya mitos dan sastra mistik yang dikembangkan oleh pegawai istana, raja, pujangga, dan arsitek. Mitos diciptakan penguasa untuk melanggengkan kekuasaan sedangkan seni budaya dugunakan untuk kepentingan islamisasi. Budaya populer kerap mengadopsi konsep dan simbol Islam sehingga muncul asumsi bahwa Islam merupakan sumber kebudayaan yang penting dalam budaya populer di
Indonesia. Fakta ini dilihat dari kosakata Melayu dan Jawa menggunakan bahasa Arab seperti: wahyu, ilham, wali, ilmu, adab, paham, dan sebagainya, (Moeflich Hasbullah, 2017).

Dalam konteks Minangkabau yang merupakan daerah agraris, nagari memiliki posisi yang strategis dalam perkembangan sosial dan politik, hal ini didukung dengan ungkapan adat salingka nagari. Di masa pra Islam adat merupakan sumber penting dalam menentukan nilai dan norma yang berkembang di masyarakat. Islam yang datang setelah adanya adat memiliki sistemnya sendiri sehingga sedikit terjadi perbedaan di antara keduanya. Islam yang memiliki ciri khas universal dan bagian dari fenomena urban, sedangkan sebuah tradisi berangkat dari perilaku yang bersifat tidak statis, namun merupakan hasil dialog yang berkembang di masyarakat sebagai referensi bersama yang lahir dari peristiwa kreatif tertentu. Dengan datangnya Islam maka terjadinya kesesuaian antara agama dan adat sebagai yang tercantum dalam ungkapan syarak basentak naik, adat basentak turun, (Mestika Zed, 2010).

Hubungan antara agama dan budaya menghasilkan sintesis (membentuk sebuah budaya baru), asimilasi (percampuran), dan akulturasi (budaya gabungan). Hubungan tersebut terjadi secara persuasif dan saling menjaga dalam keasliannya. Islam sebagai ajaran normatif yang berasal dari Tuhan diakomodasikan ke dalam kebudayaan yang berasal dari manusia tanpa kehilangan identitasnya masing-masing. Sehingga tidak diperlukan lagi proses 
pemurnian Islam atau menyamakan dengan praktek keagamaan masyarakat di Timur Tengah. Ide mengenai Arabisasi akan berdampak kepada tercerabutnya sebuah masyarakat dari budaya yang mereka tempati, (Wahyuni, 2018).

Islam sebagai tradisi memiliki corak keberagamaan yang bersifat rasionalitas atau alasan kebenaran yang mengacu pada teks agama, sejarah, dan isntitusinya. Disebut dengan praktek Islam disebabkan oleh adanya pemberian otoritas oleh ulama, khatib, sufi, dan sebagainya. Hal ini dapat menghubungkan antara masa lalu (praktek agama yang telah tetap), masa akan datang (berlangsungnya praktek tersebut di masa mendatang), dan pelaksanaannya pada masa kini, (Asliah Zainal, 2018).

Proses persentuhan antara Islam dan budaya di Minangkabau banyak mengalami pasang surut, bahkan menimbulkan konflik di antara dua kubu yang memiliki peran besar di Minangkabau. Iskandar Kemal sebagaimana dikutip oleh Donald Qomaidiansyah Tungkagi menjelaskan ada dua golongan yang memegang penting di Minangkabau, yaitu kaum adat atau orang yang masih terikat pada adat yang lama dan golongan masyarakat individu yang terdiri dari golongan alim ulama, cerdik pandai, pemuda serta kelompok yang telah mengalami perubahan yang evolutif. Di antara dua kelompok ini memiliki pertentangan antara mempertahankan adat dan kelompok yang berusaha menghilangkan penyimpangan dalam konteks agama. Hal ini menjadi pemicu perang Padri, Belanda atas permintaan kelompok adat berhasil mengatasi konflik ini di tahun 1838 dan berusaha memberlakukan aturan kolonial di daerah Minangkabau, (Donald Qomaidiansyah Tungkagi, 2017).

Snouck Hurgronje menilai teori hukum receptio yaitu Islam sebagai agama atau hukum normatif dapat diterima di masyarakat jika tidak bertentangan dengan budaya. Teori di atas menunjukkan bahwa proses persentuhan antara agama Islam dengan budaya Minangkabau melalui yang memiliki dinamika yang berujung pada negoisasi di mana penerimaan budaya terhadap nilainilai Islam menjadi proses saling melengkapi antara satu dengan yang lain, sesuai dengan filosofi syarak mangato adat mamakai Tuhan bersifat qadim manusia bersifat khilaf.

\section{Basafa sebagai Kegiatan Manjalang Guru dan Memperkuat Silaturahim Jamaah}

Pada awalnya, Islam yang mulamula masuk ke Nusantara memiliki karakteristik yang lembut dan dibawa oleh tokoh sufistik sehingga tidak didapati catatan pertumpahan darah ketika datangnya Islam di Nusantara. Hal ini didasari oleh sifat dan sikap para sufi yang cenderung kompromi dan penuh kasih sayang. Suburnya tasawuf sering ditemukan daerah yang dikenal kosmopolitan yang tidak lagi mempersoalkan perbedaan etnis, ras, bahasa dan geografis. Hal ini yang menyebabkan misi para sufi menjadi berkembang tanpa peran karena lebih mengutamakan pergaulan dengan 
kelompok masyarakat kecil serta keteladanan, (Sutejo Ibnu Pakar, 2015).

Ajaran tasawuf yang bercorak Persia berkembang di kawasan Nusantara pada abad XIII hal ini disebabkan masyarakat telah memiliki dasar ajaran mengenai ke Tuhanan sebelumnya. Setelah itu, Islam menjadi subur. Adat yang berlaku di masyarakat disesuaikan dengan ajaran Islam karena adat pada dasarnya selalu mengajarkan mengenai kebaikan, (Boestami, 1981).

Persentuhan ulama dan masyarakat di Nusantara telah menjadi hubungan mutualis simbiotik (saling membutuhkan), karena ulama berkepentingan dalam menyampaikan dakwahnya sedangkan masyarakat membutuhkan pencerahan dari perilaku-perilaku yang selama ini dianggap menyimpang dari agama. Di Minangkabau Syekh Burhanuddin merupakan penyebar Islam yang sukses meskipun sebelum beliau sebenarnya telah ada, namun masih dikatakan belum banyak masyarakat yang tertarik untuk mempelajari Islam (KhalifahSyekh Burhanuddin ke-15, 2018).

Masih menurut Heri Firmansyah Tk Khalifah Syekh Burhanuddin merupakan ulama keturunan Pariangan Padang Panjang. Beliau lahir dari seorang bapak yang bernama Pampak Sati Karimun Merah dan Ibu Puti Cukuik Bilang Pandang. Ketika masih kecil orang tua beliau selalu menanamkan budi pekerti yang halus dan selalu dibawa belajar kepada Illapai seorang pedagang dari Gujarat. Semangat belajar yang tidak pernah kendur menemukan beliau kepada Syekh Abdullah Arif Tuanku Madinah.
Setelah beberapa tahun belajar, guru tersebut merekomendasikan kepada Syekh Burhanuddin untuk melanjutkan pendidikan kepada Syekh Abdurrauf di Aceh.

Di Aceh ini intelektual Syekh Abdurrauf semakin terasah, hal ini terbukti dengan sekembalinya beliau dari Aceh yang menempa ilmu selama 28 tahun, ranah Minang telah banyak mengalami kemajuan terutama di bidang keagamaan. Syekh Burhanuddin wafat pada Jum'at 13 Safar 1111 H sebagaimana diungkap oleh murid beliau Idris ibn Salim dan Abdurahman. Para muridmurid beliau mengangkat Idris ibn Salim sebagai khalifah pertama dari Syekh Burhanuddin (Tim Penulis, 2007). Terdapat beberapa kesepakatan dari murid-murid beliau sebelum pulang ke kampung masing-masing untuk mengembangkan Islam, di antaranya: Pertama, melakukan pertemuan setiap tahun di makam guru pada Rabu malam Kamis antara tanggal 11-17 di bulan Safar; Kedua, mengadakan ziarah dan mendoakan guru dengan mengajak para murid dan jamaah masing-masing; Ketiga, melakukan pengajian dan pengkajian sesama murid dan pengikut Syekh Burhanuddin dalam rangka mengembangkan dakwah Islamiyah

Dalam beberapa catatan sejarawan, dalam mengembangkan dakwah Islam metode yang diterapkan oleh Syekh Burhanuddin hampir mirip yang dilakukan oleh Wali Songo, beliau mengikuti beberapa tradisi setempat kemudian memasukkan nilai-nilai Islam ke dalam tradisi tersebut. Di antaranya kebiasaan pemuda di zaman beliau 
bermain tondeh dengan damar keras, bermain kelereng dan sebagainya. Beliau mengikuti permainan tersebut dengan didahului doa dan memenangkan permainan sehingga anak-anak yang lain menjadi kagum dan bertanya doa apa yang dibaca sebelum bermain agar menang. Maka Syekh Burhanuddin mengajarkan

bismillahirrahmanirrahim. kalimat Syekh

Burhanuddin melakukan islamisasi tidak dengan kekerasan dan pedang namun dengan interaksi yang bagus sehingga masyarakat menjadi nyaman (Imam Maulana Abdul Manaf, 2001).

Pelaksanaan kegiatan basafa pada saat ini mengalami perkembangan karena murid Syekh Burhanuddin telah menyebar ke berbagai daerah, di antaranya: Sumatera Barat, Jambi, Riau, Bengkulu dan daerah lainnya. Dalam pelaksanaan basafa, menurut Heri Firmasnyah Tk. Khalifah, ada beberapa hari, di antaranya: Pertama, Safa Gadang, pelaksanaannya adalah bagi jamaah yang datang dari daerah darek yang dilakukan pada hari Rabu di atas tanggal sepuluh bulan Safar; Kedua, Safa Ketek, dilaksanakan bagi masyarakat yang berasal dari daerah rantau (Padang Pariaman) dan sekitarnya. Pelaksanaannya hari Rabu seminggu setelah kegiatan safa gadang; Ketiga, Safa Buya Ungku Shaliah, dilakukan pada hari Sabtu setelah safa ketek, kegiatan ini dilakukan oleh jamaah Buya Ungku Shaliah yang bermakam di Sungai Sariak. Hal ini dilakukan oleh jamaah tersebut untuk mengenang jasa Syekh Burhanuddin yang telah mengembangkan ajaran tarekat Syatariyah di Sumatera Barat.

Selama kegiatan basafa para jamaah melakukan beberapa kegiatan, di antaranya shalat sunat, zikir, berdoa, sedekah, dan ibadah lainnya yang mendekatkan diri seseorang kepada Allah. Kegiatan basafa ini dibimbing oleh tuanku yang memberikan pengarahan serta tata cara melakukan ziarah. Menurut Faisal Bismikal Adam Tk Gunung Rajo Ameh, para jamaah sebelum melaksanakan ziarah telah diberikan pengetahuan dengan wirid yang dilakukan di Surau, sedangkan materi wirid terdiri dari kajian tarekat yang berkaitan dengan paham Syekh Burhanuddin dan kaji cukuik, merupakan keterangan panjang lebar dari ajaran Syekh Burhanuddin yang dikembangkan oleh Buya Ungku Shaliah yang bertempat di Sungai Sariak (Faisal Bismikal Adam Tk Gunung Rajo Ameh, 2018).

Suryadi mengungkap ramainya jemaah yang mengunjungi Ulakan ketika Basafa dapat dilihat dari catatan Van Ronkel menjelaskan bahwa daerah Ulakan didatangi oleh jamaah yang berjumlah puluhan ribu orang. Orang-orang alim antrean di halaman masjid sehingga sulit untuk bergerak. Barisan perempuan yang menggunakan penutup kepala (tilakuang) juga memadati halaman masjid. Sedangkan di sekitar makam Syekh Burhanuddin terdengar suara laa ilaaha illa Allah (tahlil) ribuan kali dengan menggeleng-gelengkan kepala. Sedangkan amalan yang lain adalah dengan membaca al-Fatihah dan surat Yasin (Suryadi, 2018). 
Ritual yang dilakukan oleh masyarakat muslim terbagi kepada dua hal: ritual formal dan ritual popular. Perbedaan di antara keduanya, ritual formal ditentukan jenis, cara, ruang dan waktunya. Sedangkan ritual popular merujuk pada praktek ritual yang telah dimandatkan oleh sumber utama Islam, seperti Maulid Nabi, perayaan 10 Muharam dan ziarah dengan berbagai tata caranya. Ritual popular bersifat dinamis dan berubah sesuai dengan perkembangan ilmu pengetahuan dan penafsiran terhadap teks tertulis. Beberapa pendekatan telah dilakukan dalam mengkaji hal-hal yang berkaitan dengan ritual popular, di antaranya: teori fungsional, teori rite de passage (perubahan ritual) dan teori struktural (Purwadi, 2016). Tradisi basafa merupakan ritual popular yang dilakukan jamaah Syatariyah dalam memperkuat paham Syatariyah yang diajarkan oleh guru serta upaya dalam menjaga ketersambungan guru. Meskipun pada sebagian kegiatan terdapat penyimpangan yang dilakukan jamaah dikarenakan semangat keberagamaan yang tinggi tanpa dibarengi oleh ilmu pengetahuan, namun hal ini tidak dapat digeneralisir secara keseluruhan dan dianggap sebagai kesalahan.

Perilaku ritual keberagamaan peziarah ke makam wali dan ulama didasarkan atas berbagai ritus yang dibangun dalam sistem sosial yang hidup dalam masyarakat peziarah. Upacara keagamaan yang dilakukan di makam merupakan aspek religi yang dibingkai oleh suatu keyakinan terhadap kekuatan kodrati, namun dalam hal-hal tertentu tidak bisa dihindarkan dari prinsipprinsip rasional karena dilakukan dengan penuh kesadaran dan hasil dari refleksi dalam menghadapi dan menjawab berbagai permasalahan di ranah sistem sosial budaya lokal secara tradisional. Kegiatan basafa ini memunculkan beberapa kearifan lokal yang terkadang sulit dicarikan argumentasinya dalam dalil agama, di antaranya mengasumsikan kesakralan makam dengan cara melakukan lapeh niat, sebuah tradisi yang mirip dengan menunaikan nazar dan meminta berkah agar keinginan terkabulkan (Abdul Razak Salleh, 2015). Tradisi malapeh niat kerap dilakukan oleh jamaah ketika apa yang diharapkan sulit tercapai dan ketika yang diharapkan terkabul maka langsung ditunaikan. Namun fenomena lapeh niat ini menurut penulis sedikit ternoda dengan adanya perilaku ulama yang menawarkan jasa untuk menyembelih kambing dan mendoa, bahkan juga menawarkan kambing dari mereka sedangkan jamaah hanya menyediakan uang saja.

\section{PENUTUP}

Islam Nusantara merupakan gabungan dari dua kata, Islam dan Nusantara. Islam merupakan agama yang dibawa oleh Nabi Muhammad dan selanjutnta berkembang ke seluruh penjuru dunia. Sedangkan Nusantara adalah wilayah atau kawasan yang merujuk pada Indonesia dan sekitarnya di Asia Tenggara, namun tidak mencakup secara keseluruhan karena tidak semua Asia Tenggrara dimasuki oleh Islam. Terdapat dua pemahaman ketika mengkaji Islam Nusantara, pertama: kalangan, kelompok dan masyarakat 
Islam yang ada di wilayah Nusantara. Kedua, Islam yang memiliki corak tertentu dan berinteraksi secara luwes dengan tradisi atau khazanah Nusantara.

Tradisi Basafa di Ulakan merupakan sebuah penghormatan bagi seorang guru, yaitu Syekh Burhanuddin yang telah mengembangkan Islam di Minangkabau. Dalam kegiatan ini para jamaah Syatariyah berdatangan dari berbagai daerah di Sumatera barat. Ada beberapa ritual yang kerap dilakukan oleh jamaah seperti melakukan doa bersama, tahlil zikir, mandabiah kabau dimana seluruh kegiatan tersebut memiliki makna tersendiri bagi jamaah dalam menghargai dan menghormati jasa-jasa guru. Tradisi basafa merupakan bagian dari praktek cara ber-Islam masyarakat di nusantara yang mencoba menghidupkan nilai-nilai budaya setempat dalam praktek keagamaan mereka, hal ini bukan dimaksud sebagai mengada-adakan hal yang baru dalam Islam namun sebagai usaha salah satu upaya mendekatkan diri kepada Allah sebagaimana yang dipraktekkan oleh tokoh-tokoh sufi.

\section{DAFTAR PUSTAKA}

Mohamad Guntur Romli, Islam Kita Islam Nusantara: Lima Nilai Dasar Islam Nusantara (Ciputat: Ciputat School, 2016), 17.

Tim Penulis JNM, Gerakan Kultural Islam Nusantara (Yogyakarta: JNM, 2015),4.

Afifuddin Muhajir, "Meneguhkan Islam Nusantara untuk Peradaban Indonesia dan Dunia" kata pengantar dalam Ahamad Baso, Islam Nusantara: Ijtihad Jenius dan Ijma' Ulama Nusantara (Ciputat: Pustaka Afid, 2015), xv.
Azyumardi Azra, Islam Nusantara (1) kolom Resonansi tanggal 18 juni 2015, https:// republika.co diakses pada 7 Desember 2018.

Uka Tjandrasamita, Arkeologi Islam Nusantara (Jakarta: Gramedia, 2009), 21.

Muhammad Sholikhin, Ritual dan Tradisi Islam Jawa (Yogyakarta: Narasi, 2010), 27.

Moeflich Hasbullah, Islam dan Transformasi Masyarakat Nusantara: Kajian Sosiologis Sejarah Indonesia (Jakarta: Kencana, 2017), 39.

Mestika Zed, Islam dan Budaya Lokal Minangkabau Modern, Makalah disampaikan pada acara seminar internasional dengan tema: "Akar Sejarah dan Perkembangan Fundamentalisme Islam di Nusantara" oleh STAIN Djamil Djambek Bukittinggi 11 Desember 2010.

Wahyuni, Agama dan Pembentukan Struktural Sosial: Pertauatan Agama, Budaya dan Tradisi Sosial (Jakarta:Kencana, 2018), 125.

Asliah Zainal, Menjaga Adat, Menguatkan Agama Katoba dan Identitas Muslim Muna (Yogyakarata: Deepublish, 2018), 18.

Donald Qomaidiansyah Tungkagi, "Varian Islam Nusantara: Jawa, 
Minngkabau, dan Gorontalo" Jurnal Lektur Keagamaan, Vol. 15, No.2, (2017), 287.

Sutejo Ibnu Pakar, Panduan Ziarah Kubur (Cirebon: KAMU NU, 2015), 12.

Boestami, dkk., Aspek Arkeologi Islam tentang Makam dan Surau Syekh Burhanuddin Ulakan (Padang: Proyek Pemugaran dan Pemeliharaan Peninggalan Sejarah dan Purbakala Sumatera Barat, 1981), 11.

Hasil wawancara dengan Heri Firmasnsyah Tk Khalifah (Khalifah Syekh Burhanuddin ke-15) pada tanggal 25 November 2018 pukul 1400 WIB

Tim Penulis, Arti dan Makna Basafa ke Ulakan Pariaman Sumatera Barat (Jakarta: Yayasan Raudhatul Hikmah, 2007), 6.

Imam Maulana Abdul Manaf, Mubalighal Islam dialih bahasa oleh Tengku Sultan Hermansyah M.Saiman (Padang: t.p, 2001), 88.

Hasil wawancara dengan Faisal Bismikal Adam Tk Gunung Rajo Ameh, pimpinan jamaah dari Nagari Sungai Buluah Pasar Usang pada tanggal 24 September 2018 pukul 10.00 WIB.

Suryadi, "Basafa Kaum Syatariyah di Ulakan dalam Catatan Sejarah" https:/ / niadilova.wordpress.com diakses pada 10 Desember 2018 pukul 21.00 WIB.

Purwadi, Jejak Para Wali dan Ziarah Spritual (Jakarta: Kompas Media, 2006), 13.
Abdul Razak Salleh, dkk., Diaspora Adat dan Kekerabatan Alam Minangkabau (Jakarta: Kemala Indonesia, 2015), 63. 
